\title{
Attitudes in Poland Towards the Legalization of Same-Sex Registered Partnerships in the Context of Political Preferences
}

\author{
Łukasz Tomczak $^{1} \cdot$ Rafał Iwański $^{2}$ (D) $\cdot$ Katarzyna Zawadzka-Witt $^{3}$
}

Accepted: 11 March 2021 / Published online: 25 March 2021

(c) The Author(s) 2021

\begin{abstract}
Background Over recent decades, the issue of same-sex civil unions has been discussed and then legally regulated in many European Union countries. In the case of Poland, this issue is still debated in the socio-political discourse.

Methods The research presented in this article is aimed at analyzing the attitudes of Polish society towards legalization of same-sex registered partnerships. The study was nationwide and based on a quota sampling method $(n=2119)$. The data was collected in 2019.

Results An analysis of the collected data showed that the support for legalizing same-sex partnerships is not accepted by the majority of voters in Poland. However, there are differences between supporters of various political groups as well as between those who declare left-wing or right-wing views.

Conclusions For opponents of equal rights for homosexuals and heterosexuals, a crucial issue is the objection to same-sex marriage. The voters of left-wing parties and people declaring left-wing political leanings were more likely to accept other forms of marriage, although for the majority of them, marriage can be only a union between a woman and a man.

Policy Implications

The resistance of the ruling party Law and Justice, a conservative one, against legalization of same-sex partnerships and making decisions aimed at LGBT community, for instance introducing "LGBT-free zones," are one of the elements encouraging its electorate.
\end{abstract}

Keywords Registered partnership · Same-sex marriages - Voting preferences · Political parties · LGBT

\section{Introduction}

There is an ongoing debate about the legal recognition of same-sex partnerships in Poland. This issue, next to women's rights, has become one of the main problems discussed

Rafał Iwański

rafal.iwanski@usz.edu.pl

Łukasz Tomczak

lukasz.tomczak@usz.edu.pl

Katarzyna Zawadzka-Witt

katarzyna.zawadzka@usz.edu.pl

1 Institute of Political Science and Security, The head of the Laboratory of the Election Research, University of Szczecin, Krakowska 71-79, 71-003 Szczecin, Poland

2 Institute of Pedagogy, University of Szczecin, Ogińskiego 16/17, 71-415 Szczecin, Poland

3 Institute of Political Science and Security, University of Szczecin, Krakowska 71-79, 71-003 Szczecin, Poland in the context of European values. In many countries, it is possible to formalize a relationship between two persons in a form that is not a marriage by registering a partnership, sometimes also called a civil union, in the relevant office. However, solutions used in European Union countries differ significantly with regard to the very right to enter into partnership as well as to the recognition of civil unions registered abroad.

The process of legalizing same-sex unions was initiated in Europe by the Scandinavian countries (Lund-Andersen, 2012). The first to legalize same-sex partnerships was Denmark in 1989 (Badgett, 2009), and other countries have gradually followed this path (Table 1). In many countries, the process of equalizing the rights of same-sex and differentsex couples went further as same-sex marriages have been introduced (Table 2).

Poland is among those European countries in which there is no legal form of recognition of same-sex relationships. Although the first draft of law legalizing such unions was 
Table 1 The European Union countries where same-sex partnerships have been legalized

\begin{tabular}{llll}
\hline Year & Country & Year & Country \\
\hline 1989 & Denmark & 2005 & Slovenia, Spain \\
1995 & Sweden & 2006 & The Czech Republic \\
1998 & The Netherlands & 2009 & Hungary \\
1999 & France & 2010 & Austria \\
2000 & Belgium & 2011 & Ireland \\
2001 & Germany, Portugal & 2014 & Croatia, Malta \\
2002 & Finland & 2015 & Greece, Cyprus \\
2004 & Luxemburg & 2016 & Estonia, Italy \\
\hline
\end{tabular}

Cortina and Festy (2020); Lee (2010); Merin (2002); Mezey (2017); Winter (2018)

created in 2002 and followed by subsequent ones, none of them was adopted by parliament, where groups supporting the legalization of same-sex unions have not had a majority so far (Tomczak, 2012). Romania, Lithuania, Latvia, Bulgaria, and Slovakia are among other European Union countries which also do not recognize any legal form of same-sex relationships.

In 2018, the European Court of Justice ruled that the definition of a spouse in the European law is gender-neutral; therefore, same-sex marriages (EU citizens) must be recognized in all EU countries (Roseneil et al., 2020). However, the legalization of same-sex marriages still remains within the limits of law in a given country. There are cases where the rights of citizens whose countries do not have legal regulations for same-sex marriages are limited. For instance, in 2018, a court in Sofia refused to recognize the relationship of two Bulgarian citizens who got married in Great Britain. The court declared this marriage contrary to the Bulgarian Constitution and Family Code (Roseneil et al., 2020).

The possibility to legalize same-sex partnerships should be considered not only in terms of legal issues, but also social attitudes. The change in social attitudes cannot be regulated or legally enforced. The legislation helps LGBT people function in the society; however, it does not remove barriers and objections towards such regulations. There are differences here between the countries of Western and Central Eastern Europe, where the majority of adult residents had negative views on same-sex relationships, and the only exception was the Czech Republic (Foblets \& Alidadi, 2020).

The aim of the analysis carried out in the research is to explore which factors affect attitudes towards the legalization of same-sex relationships in the context of electoral preferences, sex, age, education, and place of residence. Our research is a part of a broader discussion on the acceptance of same-sex partnerships which is held in particular countries. Studies have so far indicated that there is not only a
Table 2 The European Union countries where same-sex marriages have been legalized

\begin{tabular}{llll}
\hline Year & Country & Year & Country \\
\hline 2001 & The Netherlands & 2013 & France \\
2003 & Belgium & 2014 & Luxemburg \\
2005 & Spain & 2015 & Ireland \\
2009 & Sweden & 2017 & Finland, \\
& & & Germany, \\
& & & Malta \\
2010 & Portugal & 2019 & Austria \\
2012 & Denmark & & \\
\hline
\end{tabular}

Arroyo (2017); Cortina and Festy (2020); Winter (2018)

difference among countries in the level of acceptance and evolution of social attitudes, but also that the public opinion on the right to same-sex partnerships may shape attitudes and political behaviors, including electoral preferences (Brewer, 2014).

The analysis of the results of studies conducted so far led to formulating the following research problem in given categories of respondents-in which variables condition the acceptance of the legalization of same-sex registered partnerships, same-sex marriages, and other forms of civil unions compared with those based on marriage.

In the analysis concerning political as well as social meaning of same-sex marriages, some claim that such marriages provide an opportunity for a reformulation of the role of a marriage in a society (McLaughlin et al., 2006). The opponents of same-sex marriages consider marriage an institution designed for procreation and raising children (Graham, 2004). According to supporters of same-sex marriages, a ban on such marriages is a form of discrimination based on gender, and the key arguments are the issues of fundamental freedoms and human rights (Gerstmann, 2008). At times, the opponents of legalization of same-sex marriages indicate that they harm and challenge "traditional" oppositesex marriages (Dinno \& Whitney, 2013). However, there is no evidence that granting same-sex couples the rights to marry had any influence on heterosexual marriages (Badgett, 2004). The opponents of equalization of same-sex partnerships' and marriages' rights believe that a marriage, given its special, spiritual, and cultural dimension, ought to be an institution available only to opposite-sex couples (Lee, 2010). Legalization of same-sex marriages is an important step towards the elimination of administrative barriers, constituting institutional sources of discrimination (Boertien \& Vignoli, 2019).

Studies on the legalization process of same-sex partnerships often referred to issues related to family, parenthood, and the situation of people living in same-sex relationships (Gates, 2014). The problem of legalizing such relationships also applies to the struggle for the demands of the LGBT 
movement in the field of marital equality. Studies pointed to the connection between issues related to homosexuality in the context of family and deep changes in social consciousness. Same-sex partnerships can be seen as an aspect of a wider transformation of both heterosexual and nonheterosexual relationship patterns, covering many different spheres of life and models, including what is called "families of choice" (De Filippis et al., 2018; Weeks et al., 2001).

One of the problems associated with the rights of samesex relationships is the adoption and rearing of children. Non-heterosexual parenting is the most controversial and questioned aspect related to non-heterosexual families (Weeks et al., 2001). Marriage usually involves the recognition of the legitimacy of children or the allocation of the right to children (Stone, 2012). In Poland, the demand that same-sex couples should be allowed to adopt children was also the most controversial one (Zawadzka, 2016). Polish law does not provide for granting parental rights to such couples. This does not mean that they do not raise children, but according to the law, a lesbian partner of a biological mother is a stranger to her partner's child, and therefore has no parental rights, although in practice, the two women share the parental duties (Mizielińska et al., 2014).

The issue of tolerance for relationships other than heterosexual ones is related to tolerance for homosexuals (Hooghe $\&$ Meeusen, 2013). The tolerance towards homosexuality is related to religious fundamentalism, the level of education and right-wing authoritarianism (Hildebrandt, 2015; Lambert et al., 2006; Nagoshi et al., 2008).

It has been noted that the tolerance towards homosexuality is also connected with gender. Gender-dependent differences were observed as women tended to be more accepting of homosexuality than men (Simon \& Abdel-Moneim, 2010). In Poland, men were also much less tolerant towards homosexual orientation than women (Izdebski, 2012).

What is important for legalization of same-sex partnerships is the support of political parties and the parties' relations with the LGBT movement (Peterson et al., 2018). In Poland, as in many other countries, it was the result of the elections and the position of the ruling parties that decided about the (non)implementation of the demand to legalize such partnerships (Zawadzka, 2019). There are fundamental differences in the perception of legalization of same-sex relationships by political groups in Poland. The parties on the right side of the political scene define this demand as a privilege for sexual minorities; the left parties believe that it falls within the scope of human rights (Zawadzka, 2019). Left-wing groups support the right to legalize partnerships for people of different sexual orientations, and the legal equality of marriages and informal relationships, including people of the same sex. The left is in favor of adopting the law on partnerships as a way of combating all forms of discrimination and implementing the principle of equality for all (Tomczak, 2012). The right-wing, on the other hand, defined marriage invariably as a union between a man and a woman, and the family as traditionally based on the Christian system of values. Right-wing parties declared their opposition to same-sex civil unions (Zawadzka, 2019).

A phenomenon specific to Poland was to adopt positions against LGBT community by local authorities. Their content included demands to combat, as it was referred to, "LGBT ideology," which stands in opposition to a traditional model of a family. Such documents were adopted in four out of sixteen provinces, as well as in lower-level authorities, mainly in the southeastern part of Poland (Resolution nr X/125/19, 2019; Resolution nr VIII/140/19, 2019; Declaration Nr 1/19, 2019).

On the other hand, a conservative foundation, Institute for Legal Culture Ordo Iuris, prepared a document called Local Government Charter of the Rights of the Family, which recognized a marriage as a relationship between a man and a woman. The document was adopted by many local governments, including the authorities of one of the regions. It is estimated that by 2020, the documents restricting the rights of LGBT people, which were against the right to same-sex partnerships or marriages, were adopted on the $30 \%$ of the area of Poland. In public discourse, they were called LGBTfree zones. The zones were created in the regions with high support for right- and far-right parties. In terms of sociodemographic features, the regions do not differ against the rest of the country. However, these are poorer regions, with the average monthly disposable income per 1 person in a household amounting to $80.9-89.4 \%$ of national average (GUS, 2020).

The European Union criticized Poland for LGBT-free zones and described them as discriminating people. EU institutions relied on the values and fundamental rights of the European Union, which must be respected by the Member States (European Commission, 2020). The regions also suffered from reputational and financial consequences. In the case of the first ones, some partner municipalities from other European Union countries terminated cooperation agreements. Some of the municipalities also did not receive EU funds as a part of "Twin Cities Program," as a direct cause of the adopted resolutions.

\section{Research Methodology}

The research was conducted in 2019 in the territory of Poland. The size of the research sample was calculated on $n=1067$ respondents for the population of 38.4 million Polish residents with a confidence level of 95\%, 0.05 fraction, and maximum error of $3 \%$. In order to eliminate measurement errors, the research sample was doubled and reached the total of $n=2119$ respondents. The stratified 
Table 3 Quantitative and percentage distribution of answers to statements [A], [B], [C], and [D] (2019)

\begin{tabular}{|c|c|c|c|c|c|}
\hline Variable & Definitely no & Rather no & Hard to say & Rather yes & Definitely yes \\
\hline \multirow[t]{2}{*}{ [A] I support legalization of same-sex partnerships. $(n=2106)$} & 671 & 381 & 320 & 411 & 323 \\
\hline & $31.86 \%$ & $18.09 \%$ & $15.19 \%$ & $19.52 \%$ & $15.34 \%$ \\
\hline \multirow{2}{*}{$\begin{array}{l}\text { [B] In my opinion, marriage is only a union between a woman and a man. } \\
(n=2107)\end{array}$} & 254 & 257 & 186 & 454 & 956 \\
\hline & $12.06 \%$ & $12.20 \%$ & $8.83 \%$ & $21.55 \%$ & $45.37 \%$ \\
\hline \multirow{2}{*}{$\begin{array}{l}\text { [C] If same-sex partnerships were legalized, they should have the same } \\
\text { rights as marriages. }(n=2104)\end{array}$} & 657 & 402 & 357 & 391 & 297 \\
\hline & $31.23 \%$ & $19.11 \%$ & $16.97 \%$ & $18.58 \%$ & $14.12 \%$ \\
\hline \multirow{2}{*}{$\begin{array}{l}\text { [D] In Poland there is lack of tolerance for other forms of family life than } \\
\text { those based on marriage. }(n=2099)\end{array}$} & 98 & 280 & 423 & 770 & 528 \\
\hline & $4.67 \%$ & $13.34 \%$ & $20.15 \%$ & $36.68 \%$ & $25.15 \%$ \\
\hline
\end{tabular}

quota sampling method was applied in the research. The size of a sample was calculated for each of 16 provinces in the country considering the distribution with regard to age (6 categories), place of residence (city/village), and sex, based on the demographic data from the Statistics Poland (GUS) for 2018. The pollsters, while selecting respondents in their areas, used the research implementation card with a specified number of respondents in a given group on grounds of sex, age, and place of residence.

The survey used the author's own questionnaire, which consisted of 87 questions and statements divided into 10 modules.

The pollsters selected respondents on the basis of a research implementation card developed for this study. The respondents completed the questionnaires themselves; the role of the pollster was to provide and collect complete surveys.

The analysis covered 2119 correctly completed questionnaires, qualified in accordance with the assumed criteria for selecting the sample.

The respondents could determine their level of acceptance of same-sex civil unions by expressing on a Likert scale their response towards four statements:

- [A] I support legalization of same-sex partnerships.

- [B] In my opinion, marriage is only a union between a woman and a man.

- [C] If same-sex partnerships were legalized, they should have the same rights as marriages.
- [D] In Poland, there is a lack of tolerance for other forms of family life than those based on marriage.

The statistical significance tests were nonparametric. In order to verify the assumptions about the significance of differences between the medians of the studied variables, a Mann-Whitney $U$ test was used (one of the variables had only two groups), and the Kruskal-Wallis independence test was applied for variables without a large number of categories. To check the dependence of qualitative features, a Spearman rank coefficient was calculated.

\section{Results}

Without distinguishing individual categories, the results of the responses to the statements showed a dominance of people against the legalization of same-sex relationships (49.95\%) over supporters of legalization (34.86\%) in the entire population of respondents. Almost every third respondent, $31.86 \%$, strongly disagreed, and only $15.35 \%$ were definitely in agreement with statement [A]. Among all respondents, $15.19 \%$ did not have an opinion on this subject (Table 3).

The majority of the respondents, $66.92 \%$, agreed with the statement [B] that marriage is only a union between a woman and a man, and $45.37 \%$ of the respondents agreed definitely. A total of $24.26 \%$ were of the opposite opinion, and only $8.83 \%$ of the respondents had no opinion on this

Table 4 Mann-Whitney $U$ test for the variable "sex" (2019)

\begin{tabular}{|c|c|c|c|c|c|}
\hline Variable & $U$ & $Z$ & $p$ & $Z$ (corrected) & $p$ \\
\hline [A] I support legalization of same-sex partnerships & $518,082.5$ & 2.53898 & 0.011118 & 2.6088 & 0.009086 \\
\hline [B] In my opinion, marriage is only a union between a woman and a man & $504,371.5$ & -3.55621 & 0.000376 & -3.76464 & 0.000167 \\
\hline $\begin{array}{l}\text { [C] If same-sex partnerships were legalized, they should have the same } \\
\text { rights as marriages }\end{array}$ & $485,970.5$ & 4.77931 & 0.000002 & 4.90744 & 0.000001 \\
\hline $\begin{array}{l}\text { [D] In Poland there is lack of tolerance for other forms of family life than } \\
\text { those based on marriage }\end{array}$ & $496,328.5$ & 3.85016 & 0.000118 & 4.00525 & 0.000062 \\
\hline
\end{tabular}

* Result statistically significant for $p<0.05$ 
Table 5 Kruskal-Wallis test for variables: age, place of residence, education, and distribution of political preferences on the right-left axis (2019)

\begin{tabular}{|c|c|c|c|c|}
\hline Variable & Age & Place of residence & Education & Right-left axis \\
\hline $\begin{array}{l}\text { [A] I support legalization } \\
\text { of same-sex partnerships }\end{array}$ & $\begin{array}{l}\mathrm{H}(6, N=2106)=53.69617 \\
p=.0000\end{array}$ & $\begin{array}{l}\mathrm{H}(6, N=2106)=83.41304 \\
p=.0000\end{array}$ & $\begin{array}{l}\mathrm{H}(3, N=2067)=88.92087 \\
p=0.000\end{array}$ & $\begin{array}{l}\mathrm{H}(5, N=2101)=432.7883 \\
p=0.000\end{array}$ \\
\hline $\begin{array}{l}\text { [B] In my opinion, mar- } \\
\text { riage is only a union } \\
\text { between a woman and } \\
\text { a man }\end{array}$ & $\begin{array}{l}\mathrm{H}(6, N=2107)=59.61413 \\
p=.0000\end{array}$ & $\begin{array}{l}\mathrm{H}(6, N=2107)=47.29201 \\
p=.0000\end{array}$ & $\begin{array}{l}\mathrm{H}(3, N=2069)=49.61679 \\
p=.0000\end{array}$ & $\begin{array}{l}\mathrm{H}(5, N=2101)=306.8138 \\
p=0.000\end{array}$ \\
\hline $\begin{array}{l}\text { [C] If same-sex partner- } \\
\text { ships were legalized, they } \\
\text { should have the same } \\
\text { rights as marriages }\end{array}$ & $\begin{array}{l}\mathrm{H}(6, N=2104)=40.51751 \\
p=.0000\end{array}$ & $\begin{array}{l}\mathrm{H}(6, N=2104)=77.23337 \\
p=.0000\end{array}$ & $\begin{array}{l}\mathrm{H}(3, N=2065)=57.64588 \\
p=.0000\end{array}$ & $\begin{array}{l}\mathrm{H}(5, N=2098)=375.1213 \\
p=0.000\end{array}$ \\
\hline $\begin{array}{l}\text { [D] In Poland there is lack } \\
\text { of tolerance for other } \\
\text { forms of family life than } \\
\text { those based on marriage }\end{array}$ & $\begin{array}{l}\mathrm{H}(6, N=2099)=15.87000 \\
p=.0145\end{array}$ & $\begin{array}{l}\mathrm{H}(6, N=2099)=10.24899 \\
p=.1146\end{array}$ & $\begin{array}{l}\mathrm{H}(3, N=2060)=25.98904 \\
p=.0000\end{array}$ & $\begin{array}{l}\mathrm{H}(5, N=2093)=166.6245 \\
p=0.000\end{array}$ \\
\hline
\end{tabular}

*Result statistically significant for $p<0.05$

subject. Every third respondent (32.7\%) agreed with the statement [C] that in the case of legalization of same-sex partnerships, they should have the same rights as marriages, but only $14 \%$ of the respondents expressed firm support. Half of the respondents (50.34\%) were of the opposite opinion, and $31.23 \%$ strongly opposed the statement [C]. The majority, $61.78 \%$, of the respondents agreed with statement [D] that in Poland, there is lack of tolerance for other forms of family life than those based on marriage. Every fifth respondent had no opinion, and around 18\% thought that there was no problem with tolerance in this matter.

The results of the Mann-Whitney $U$ test showed statistically significant gender-related difference in the respondents' answers for each of the analyzed statements in the answer distribution, with $p$ set as $<0.05$ (Table 4).

The results of the Kruskal-Wallis test for variables with more categories indicate that, according to the adopted assumptions that $p<0.05$, the distribution of answers in the case of age, education (primary, vocational, secondary, and higher), and electoral preferences on the left-right axis are statistically significant for all statements analyzed (Table 5). In the case of place of residence, statistical significance was not found only with regard to statement [D] (Table 5).
In the case of all statements, there were statistically significant correlations at $p<0.01$. Weak correlations dominated for sex, age, place of residence, and education, except for statement $[\mathrm{B}]$ and the education factor, where a low correlation was noted. A clear correlation was noted for all the statements and the political preference factor of the right-left axis (Table 6).

Supporters of legalization of same-sex relationships opposed the statement that marriage is only a relationship between a woman and a man. A strong negative correlation $(-0.66)$ was noted between the answers to statements [A] and $[\mathrm{B}]$. Also, a high negative dependence $(-0.62)$ was observed between statements [B] and [C]. Those respondents who thought that marriage was a union only between a woman and a man did not agree to give same-sex partnerships the same rights as marriages. A strong positive correlation (0.71) was noted between statements [A] and [C]. Supporters of legalization of same-sex partnerships agreed to grant them the same rights as marriages. A weak positive correlation was noted between the distribution of the respondents' answers regarding statements [A] and [D] (0.36) and [C] and [D] (0.36). However, in the case of the answers regarding statements $[\mathrm{B}]$ and $[\mathrm{D}]$, a weak negative

Table 6 Spearman's rank-order correlation of questions regarding sex, age, place of residence, education, and political preferences on the rightleft axis (2019)

\begin{tabular}{|c|c|c|c|c|c|}
\hline Variable & Sex & Age & Place of residence & Education & Right-left axis \\
\hline [A] I support legalization of same-sex partnerships & $-0.06 * *$ & $-0.15 * *$ & $0.18 * *$ & $0.21 * *$ & $-0.35 * *$ \\
\hline [B] In my opinion, marriage is only a union between a woman and a man & $0.08^{* *}$ & $0.16^{* *}$ & $-0.12 * *$ & $-0.15 * *$ & $-0.29 * *$ \\
\hline $\begin{array}{l}\text { [C] If same-sex partnerships were legalized, they should have the same } \\
\text { rights as marriages }\end{array}$ & $-0.11^{* *}$ & $-0.10^{* *}$ & $0.17 * *$ & $0.16^{* *}$ & $-0.33 * *$ \\
\hline $\begin{array}{l}\text { [D] In Poland there is lack of tolerance for other forms of family life than } \\
\text { those based on marriage }\end{array}$ & $-0.09 * *$ & $-0.06 * *$ & $0.07 * *$ & $0.09 * *$ & $-0.21 * *$ \\
\hline
\end{tabular}

$* * p<0.01$ 
Table 7 Spearman's rank-order correlation (2019)

\begin{tabular}{|c|c|c|c|c|}
\hline Variable & {$[\mathrm{A}]$} & [B] & {$[\mathrm{C}]$} & [D] \\
\hline [A] I support legalization of same-sex partnerships & $1.00 *$ & $-0.66^{*}$ & $0.71 *$ & $0.36^{*}$ \\
\hline [B] In my opinion, marriage is only a union between a woman and a man & $-0.66^{*}$ & $1.00 *$ & $-0.62 *$ & $-0.29 *$ \\
\hline $\begin{array}{l}\text { [C] If same-sex partnerships were legalized, they should have the same rights as } \\
\text { marriages }\end{array}$ & $0.71 *$ & $-0.62 *$ & $1.00 *$ & $0.36^{*}$ \\
\hline $\begin{array}{l}\text { [D] In Poland there is lack of tolerance for other forms of family life than those } \\
\text { based on marriage }\end{array}$ & $0.36^{*}$ & $-0.29 *$ & $0.36^{*}$ & $1.00 *$ \\
\hline
\end{tabular}

*Correlations are significant with $p<0.05$

dependence was observed $(-0.29)$. All the noted correlations are statistically significant with $p<0.05$ (Table 7).

In the oldest age category, $60.1 \%$ of the respondents opposed, and $42.96 \%$ strongly opposed statement [A]. In this age category, $25.12 \%$ of the respondents expressed support for statement [A]. Along with the decrease in age, the percentage of respondents opposing statement [A] systematically dropped to the level of $42.92 \%$ in the $25-34$ age category. In the youngest category, there was a slight increase in opponents (to $44.18 \%$ ), but also the highest percentage of supporters $(47 \%)$ for statement [A]. Only in the youngest age category supporters of same-sex relationships outweighed their opponents, and the percentage of those who had no opinion on this topic was the smallest compared to other categories.

In the youngest age group, about $59.37 \%$ of women were in favor of legalizing same-sex partnerships, and there were only $34.29 \%$ of such responses among men. In this age category, three times as many women as men expressed strong support for statement [A]. Only $15.84 \%$ of women in the analyzed age category expressed strong opposition to statement [A]; among men, this attitude was expressed by $37.14 \%$ of the respondents.

The distribution of answers by place of residence indicates that there were statistically significant differences due to the size of towns (Table 4). The lowest $(21.98 \%$ ) support for statement [A] was expressed by the inhabitants of rural areas (with agriculture-based economy). In this group, there was the highest percentage (63.04\%) of those opposed to this statement.

Education of the respondents was a statistically significant factor (Table 5). A clear relationship was found between education and support for the statement in question (rho $=0.21, p<0.01$ ). The highest $(43.79 \%$ ) support for legalization of same-sex relationships was in the group of people with higher education. In the group of the least educated, support for statement [A] amounted to $22.3 \%$.

There were clear statistically significant differences in support for same-sex partnerships between the respondents declaring right-wing and left-wing views $(\mathrm{H}(5, N=2101)=432.7883 p<0.01)$. There was a clear dependence between political preferences and support for legalization of same-sex relationships ( $\mathrm{rho}=-0.35 p<0.01$ ).

The closer the respondents were to right-wing views, the less support for statement [A] was expressed. Legalization of same-sex relationships received support from $66.97 \%$ of the respondents with left-wing views and $69.33 \%$ of the respondents with center-left. However, about $23.4 \%$ of those with left-wing views and $20.89 \%$ with center-left views were against it. In the group of voters defining their views as centrist, the percentage of supporters and opponents was similar.

In the group of voters with right-wing views, the majority (76.96\%) was against same-sex unions, and $63.09 \%$ were definitely against. In this group, only $13.87 \%$ of the respondents were in favor of statement [A]. Opponents of legalization of such unions outnumbered its supporters three times also among center-right voters.

With regard to statement [B], the distribution of answers showed statistically significant differences related to age and sex (Tables 4 and 5) as well as a weak correlation for sex $($ rho $=0.08 p<0.01)$ and age $($ rho $=0.16 p<0.01)$ (Table 6). The older the respondents were, the more answers supporting the presented view were given. In the oldest age category, $79.89 \%$, and in the youngest $56.68 \%$ of respondents agreed with the statement that a marriage is a union between a man and a woman. The differences between the sexes were noted in all categories, but the largest were in the case of the youngest group of respondents. The lowest (46\%) support for statement [B] was expressed by women from the youngest age category, while the support for this statement expressed by men was $66.67 \%$ in this category. In turn, in the same age category of respondents (the youngest), $42 \%$ of women and $21.9 \%$ of men did not agree with statement [B], while in the oldest age group, $18.9 \%$ of women and $15.02 \%$ of men chose this answer.

In the distribution of answers, there were statistically significant differences related to education of the respondents $(p<0.01)$ (Table 5). The vast majority $(74.19 \%)$ of people with primary education agreed with statement [B], whereas in the group of people with higher education, $59.97 \%$ of the respondents expressed their support. There is a noticeable 
dependence (rho $=-0.15 p<0.01)$ - the more educated the respondents, the more answers opposed the presented view (Table 6).

An important factor differentiating the distribution of answers was the place of residence $(p<0.01)$ (Table 5). A weak statistically significant dependence between the size of places of residence and the support for the presented view was noted (rho $=-0.12 p<0.01)$ - the smaller the community, the stronger support for statement [B].

With regard to statement [B], in the distribution of answers, there were statistically significant differences related to the right-left axis (Table 5). Support for the statement that marriage is only a union between a woman and a man decreased with the shift towards the left-wing end of the spectrum. In the group of the respondents who defined their views as right-wing, $84 \%$ expressed their support; in the center-right $78.53 \%$, centrist $62.63 \%$, center-left $44.89 \%$, and left-wing $36.58 \%$. The opponents of this statement constituted the majority (51.38\%) only among the left-wing voters.

The largest percentage of the respondents for whom marriage is only a union between a woman and a man was among those voting for right-wing parties-between 75 and $85.36 \%$. The respondents supporting left-wing parties were of a different opinion.

With regard to statement [C], in the distribution of answers, there were statistically significant differences related to sex (Table 3), and a statistically significant distribution of answers related to place of residence $(\mathrm{H}(6$, $N=2104)=77.23337 p<0.01)$ (Table 5). Inhabitants of villages expressed the lowest support for equating the rights of same-sex registered partnerships with marriages-19.18\%. In the case of the remaining groups, there is a noticeable dependence that the larger the city, the greater the support for equal rights $($ rho $=0.17 p<0.01$ ).

A statistically significant dependence between education and support for equal rights for same-sex unions and marriages was noted $($ rho $=0.16 p<0.01)($ Table 4$)$-the higher the education of the respondents, the more support for equal rights. In the group of people with higher education, this view was expressed (with varying decisiveness) by $39.81 \%$, with secondary education- $31.21 \%$, with vocational education $21.13 \%$, and with primary education-only $15.96 \%$. Most often, opposition to equal rights was expressed by respondents with the lowest education-64.9\%.

With regard to statement [C], in the distribution of answers, there were statistically significant differences related to the right-left axis $(9 \mathrm{H}(5, N=2098)=375.1213$ $p<0.01)$. Support for equating the rights of same-sex unions with marriages increased with the shift to the left of the political spectrum, and the number of opponents increased with the shift to the right (rho $=-0.33 p<0.01)$ (Table 5). A total of $64.98 \%$ of the respondents declaring their views as left-wing supported equating the rights of same-sex unions with marriages, while $21.2 \%$ of this group was of the opposite opinion. A total of $75.17 \%$ in the group of right-wing voters and $61.54 \%$ in the center-right were against equating the rights of same-sex unions with marriages. A total of $14.68 \%$ of voters with right-wing views and $21.46 \%$ with center-right views supported the equality of rights in this respect.

With regard to statement [C], in the distribution of answers, there were statistically significant differences related to the age of the respondents (Table 5) - the older the voters, the higher the percentage of those disagreeing with statement $[\mathrm{C}]$. The highest support was found in the age groups 18-24 (40.2\%) and 35-44 (39.3\%). In the youngest age group, there were clear gender-related differences. Women $(53.53 \%)$ were twice as likely to agree with statement $[C]$ than men $(27.62 \%)$.

The majority of voters of left-wing parties supported equalizing the rights of same-sex unions with marriages. In the group of respondents voting for right-wing parties, the dominant view was against equal rights for same-sex unions and marriages.

With regard to statement [D], in the distribution of answers, there were statistically significant differences related to the age of the respondents $(\mathrm{H}(6, N=2099)=15.87000$ $p<0.01)$. The largest percentage of respondents who agreed that in Poland there is lack of tolerance for other forms of family life than those based on marriage was in the categories of 35-44 years (66.83\%) and 18-24 years (63.72). The smallest percentage was in the oldest group, $54.27 \%$ of the respondents agreed with this statement.

There are significant gender-related differences in individual age categories $(p<0.01)$. Women more often than men indicated the lack of tolerance. The largest differences were noted in the youngest category, in which $78 \%$ of women and $50 \%$ of men indicated the lack of tolerance.

With regard to statement [D], in the distribution of answers, there were statistically significant differences related to education (Table 5). Only in the group of voters with primary education the people agreeing with statement [D] constituted less than half (46.8\%) of the respondents. In the group of voters with vocational education, it was $51.34 \%$, and among voters with secondary and higher education, about $65 \%$ in each group.

With regard to statement [D], in the distribution of answers, there were statistically significant differences related to the right-left axis $(\mathrm{H}(5, N=2093)=166.6245$ $p<0.01$ ). A total of $78.81 \%$ of the respondents declaring left-wing views and $81.86 \%$ center-left stated that in Poland, there is a lack of tolerance for other forms of family life than those based on marriage. Among the respondents who were voters of center-right and right-wing parties, this view was shared by a minority ( $49.59 \%$ and $44.82 \%$, respectively). 
The highest percentage of respondents agreeing with statement [D] was noted among the voters of the Together Party (81.81\%), KO (77.71\%), and SLD (70.74\%). The lowest percentage of respondents who agreed with statement [D] was among the voters of RN (53.33\%) and PiS (45.74\%).

\section{Discussion}

The demand for the legalization of same-sex unions is not accepted by the majority of voters in Poland, and there are clear differences in this respect between supporters of individual parties. The dividing line regarding support for same-sex unions clearly distinguishes the attitude of voters of left-wing parties from those supporting right-wing ones. Those voters who defined their views as left-wing or centerleft and who supported left-wing parties during the elections were more likely to accept same-sex registered partnerships. In turn, those respondents who defined their views as centerright, or especially right-wing, and voted for right-wing parties, were mostly against the legalization of same-sex unions.

The issue does not only revolve around supporting samesex unions but also around equating their rights with marriages. The research conducted in European countries also confirmed that people with conservative views more often have a negative attitude towards equalizing the rights of same-sex partnerships and marriages (Hollekim et al., 2012).

Similar dependencies can be observed in other countries, for example in the USA, where opinions on the rights of same-sex marriages are also divided along party, ideological, and religious lines (Kaufman \& Compton, 2020; Linneman, 2004). Liberals, Democrats, and less religious people are more accepting of same-sex marriages. In turn, those who oppose such equality belong to conservative, Republican, and Protestant circles (Lewis \& Gossett, 2008). This may result from the dislike for the homosexual minority itself and thus unwillingness to cater to their demands. This corresponds to the research of Harrison and Michelson who also noticed the dependence between attitudes towards homosexuals and political views-the more right-wing the views, the stronger the prejudices against gays and lesbians (Harrison \& Michelson, 2017).

In Poland, there are many more voters who declare rightwing and center-right views and vote for parties that are on the right of the political scene than those who declare leftwing views and support for such parties. The position taken by the ruling party, the kind of dominance it has in local authorities, and the views represented by the voters of the party residing in a particular region are of key importance in the process of legalization of same-sex partnerships and attitude towards LGBT community (Mariani, 2020). Political parties which did not support the legalization of same-sex unions have been controlling the majority of parliamentary seats since the system transformation in 1989, yet the dispute over the legalization of same-sex unions has not been part of the division between the government and the opposition as politicians opposed to such unions were found on both sides (Bodnar \& Śledzińska-Simon, 2014).

In eastern Poland, the majority of mandates in collegial local authorities was controlled by the conservative party Law and Justice (PiS). It was on the initiative of councilmen representing this party that local authorities passed resolutions on creating LGBT-free zones.

The percentage of respondents who were against the legalization of same-sex relationships in eight regions of eastern Poland constituted between $53.85 \%$ and $64.16 \%$. In the remaining eight regions, it amounted between $30.53 \%$ and $49.73 \%$. There were more supporters than opponents of same-sex relationships' legalization in three regions. Respondents gave similar answers when divided into regions in the case of a claim that a marriage is a relationship exclusively between a man and a woman, and that same-sex partnerships should not have the same rights as marriages. A group of regions with the highest percentage of respondents being against same-sex partnerships' legalization included the regions where the authorities decided to create LGBTfree zone.

In many countries, same sex partnerships were legalized when right-wing parties (co)formed the governments. For example, in Austria in 2010, when the law legalizing partnership unions came into force, the Christian-democratic Österreichische Volkspartei co-ruled with social democrats. In Great Britain, the idea of introducing same-sex marriages was supported by the conservative Prime Minister David Cameron, although the politicians from his party were divided on the subject.

In Poland, conservative groups were definitely against legalizing same-sex partnerships (Zawadzka, 2016). The research confirms the convergence of their views with the expectations of their voters. Supporters of right-wing parties and those declaring right-wing views proved to be more resolute in their views than supporters of the left. In this case, there are interesting differences related to respondents who expressed their views decisively. Respondents claiming to be right-wing more often expressed strong opposition to same-sex unions than left-wing voters did for their strong support. A relatively large percentage of left-wing voters with center-left views declaring their opposition to support for same-sex unions is also noteworthy.

With the increase in age of respondents, there was a rise in the percentage of opponents of same-sex registered partnershipsolder voters, both women and men, mostly opposed them. Younger respondents were against to a smaller extent, but here, there were significant gender-related differences. Gender is considered one of the most important factors differentiating the attitudes towards LGBT people. The results of the 
research conducted indicate that heterosexual men showed a higher level of prejudice against homosexuals than heterosexual women (Górska \& Mikołajczak, 2015; Schwartz, 2011). Our research has also revealed a significant difference between the attitudes presented by women and men among the youngest respondents. The majority of young women supported legalization of same-sex partnerships, while their male peers were mostly against them. These differences were also visible with regard to the traditional model of marriage and the demand for equating registered partnerships with marriages. Young women were less conservative in their views, contrary to young men. None of the more advanced age groups revealed such an extent of differences between men and women. Similar conclusions were drawn from the research conducted among the youth in the neighboring Czech Republic (Pitoňák \& Spilková, 2016).

Attitudes towards the legalization of same-sex partnerships changed depending on the size of a respondents' place of residence. Such unions were more often supported by people living in large cities-particularly in those with over half a million inhabitants, where $26.64 \%$ of the respondents strongly supported the legalization of same-sex partnerships, and $17.65 \%$ expressed moderate support. In turn, residents of small towns and villages were more often negative about the legalization of such relationships. Perhaps this was also due to the fact that, as other studies have shown, the inhabitants of large cities were better disposed towards gays and lesbians than people living in small towns and in rural areas (Tomczak \& Zawadzka, 2018).

Gender perspective combines with regional perspective, taking into account the relations between the place of residence and age, education, and the level of tolerance (Andersson et al., 2018). A population of gays and lesbians has been experiencing discrimination and ostracism for a long time (Florida, 2002). Gays and lesbians who live in cities tend to focus in the areas described as enclaves. A higher number of them in a given area do not always lead to a higher level of tolerance towards them. A flow of minority groups does not necessarily result in an increased contact between them and the majority (Wimark, 2014).

One of the factors that differentiated respondents in terms of acceptance of the legalization of same-sex partnerships was education level-the lower it was, the less support for the legalization of such relationships was observed. This can be related to the degree of acceptance of homosexuals in general which is also dependent on the level of education. The best-educated Poles declared more tolerant opinions, and the highest percentage of negative opinions regarding homosexuals could be found among respondents with only primary education (Górska \& Mikołajczak, 2015). Support for the legalization of same-sex partnerships was declared with definitely greater frequency by the relatively young with higher education, resident in the largest cities, and those declaring left-wing political opinions.
For opponents of equal rights for homosexuals and heterosexuals, a crucial issue is the objection to same-sex marriage. In their arguments, they express support for the traditional form of marriage and protest against any plans to redefine it (Browne \& Nash, 2015). An important voice in the Polish debate on same-sex unions is the Catholic Church, whose rhetoric expresses fear of shaking the foundation of the institution of marriage and family (Zawadzka, 2016). The process of changes in the countries where the role of a Catholic Church was or is similar is very interesting, for instance in Ireland or Italy.

Ireland has a strong historical experience in preserving discrimination in the law due to the dominant position of the Church in many spheres of life (Rodgers, 2018). In Ireland, the level of public support for changes increased gradually. The rising opposition against the discrimination of LGBT people gave rise to an organized social movement which fought conservative attitudes. In addition to this, the position of the Church weakened. In 1988, an Irish scientist David Norris began a fight for a reform of Irish law stigmatizing LGBT people. As a result of his actions, the European Court of Human Rights declared that the law criminalizing homosexuality was contrary to Article 8 of the European Convention of Human Rights (Rodgers, 2018). Further legislation evolution increased legal liberty for sexual minorities in Ireland. As a consequence of these changes, in 2015, it was stated in a referendum that a marriage may be concluded by two persons, without distinction as to the sex of the spouses (Rodgers, 2018).

Italy does not recognize same-sex marriages; however, same-sex partnerships are legalized. The process of changes was initiated in 1986, and the first draft introducing an act accepting same-sex relationships in 1988 was made on the left-wing politician initiative. The draft, as well as many consecutive ones, was rejected by the parliament and criticized by the Church. The European Court of Human Rights, which in 2015 ruled in a case Oliari and Others $v$ Italy that Italy violated the European Convention on Human Rights not recognizing same-sex partnerships' right to family life (Foblets \& Alidadi, 2020) greatly influenced the process of legalization of same-sex partnerships in Italy. It resulted in the parliament introducing the act legalizing same-sex partnerships.

The examples of Ireland and Italy may be a signal for Poland that legal recognition of same-sex partnerships, or even same-sex marriages, is possible-also in the countries where religion and the institution of Church have a significant influence on the society (Eurobarometer on Discrimination 2019).

In Polish socio-political discourse, the opponents of samesex relationships argue that homosexuality is against nature or identify it as a deviation (Zawadzka, 2019). Opponents of homosexual marriages also quote the Polish constitution, where marriage, understood as a relationship of a man and 
a woman, is protected by law. They consider opposite-sex marriages to be the right form as such civil unions perform the childbearing and childrearing functions of a family. The opponents of same-sex marriages think that children in such families will not develop properly; they also fear changes in society (Michalska, 2014). Such opinions are particularly common among residents of rural areas and small towns, where conservative attitudes are more pronounced than in large cities (Górska \& Mikołajczak, 2015).

In this study, the most conservative opinions regarding marriage only as a union between a man and a woman were declared by the inhabitants of villages in rural areas. In this aspect, the residents of large cities were less conservative. Among the voters of individual parties, opinions on same-sex marriages were distributed similar to the answers concerning support for same-sex partnerships. The voters of left-wing parties and people declaring left-wing political leanings were more likely to accept other forms of marriage, although for the majority of them, marriage can be only a union between a woman and a man. The voters on the left side of the political spectrum were less unequivocal in their opinions than the right-wing. The majority of supporters of right-wing parties, in particular PiS and $\mathrm{RN}$, subscribed to the traditional point of view on marriage. These differences were also connected with the different ways in which supporters of individual parties perceived the issue of tolerance towards other forms of family life than those based on marriage- the majority of the respondents agreed with the statement that Poles in general lack such tolerance. However, there were clear differences between the supporters of left- and right-wing parties as well as voters for individual parties. The percentage of voters agreeing with this statement decreased with the shift from the left to the right side of the political scene. Interestingly, among voters of right-wing parties, there were almost twice as many who agreed with this statement than those who disagreed. Thus, on the one hand, they agreed that in Poland, there is a lack of tolerance for same-sex partnerships, and on the other hand, they did not tolerate such partnerships as the majority of this group considered an opposite-sex marriage as the only acceptable form.

\section{Conclusions}

The results of research indicate that the conservative party Law and Justice (PiS), which has been ruling in Poland since 2015, may count on strengthening its position among voters who convey right-wing views by opposing legalization of same-sex partnerships. Passing resolutions on "LGBT-free zones" by authorities dominated by Law and Justice (PiS) may be well accepted by the right-wing voters since the legalization of same-sex partnerships is one of the postulates of LGBT communities. This way, the ruling on a local level knowingly strengthens their position among numerous conservative electorate.

The currently ruling far right-wing party PiS (Law and Justice) relies on a significant support from less educated residents of small cities and villages at a higher age. However, the views of the governing party are not shared by younger voters, in particular women aged 18-24. The preponderance of supporters of legalizing same-sex partnerships in a group of the youngest voters might suggest the decrease of the percentage of opponents with time. Such a strong trend towards radical conservative policy may result in the rejection of these values when new generations start to take active participation in political life. This may cause the change of electoral preferences and a greater support of the opposition parties. Similarly to Ireland or Italy, this may lead to a change of policy towards same-sex partnerships in the coming years.

Based on analysis of collected data, a few research areas might be distinguished which deserve special attention in the course of new research projects concerning same-sex partnerships and marriages in Poland. Future research may help explain the reasons for differences in terms of relationship acceptance in particular age groups, including in particular people who attain adulthood. In addition, it is important to seek for main predictors which have an influence on shaping attitudes of respondents.

Data Availability The data that support the findings of this study is available from the corresponding author, [R.I.], upon reasonable request.

\section{Declarations}

Ethical Approval All procedures performed in studies involving human participants were in accordance with the ethical standards of the institutional and/or national research committee and with the 1964 Helsinki declaration and its later amendments or comparable ethical standards.

Conflict of Interest The authors declare no competing interests.

Open Access This article is licensed under a Creative Commons Attribution 4.0 International License, which permits use, sharing, adaptation, distribution and reproduction in any medium or format, as long as you give appropriate credit to the original author(s) and the source, provide a link to the Creative Commons licence, and indicate if changes were made. The images or other third party material in this article are included in the article's Creative Commons licence, unless indicated otherwise in a credit line to the material. If material is not included in the article's Creative Commons licence and your intended use is not permitted by statutory regulation or exceeds the permitted use, you will need to obtain permission directly from the copyright holder. To view a copy of this licence, visit http://creativecommons.org/licenses/by/4.0/ 


\section{References}

Andersson, M., Lavesson, N., \& Niedomysl, T. (2018). Rural to urban long - distance commuting in Sweden: trends, characteristics and pathways. Journal of Rural Studies, 59, 67-77. https:// doi.org/10.1016/j.jrurstud.2018.01.010

Arroyo, Ch. (2017). Kant's ethics and the same-sex marriage debate - An introduction. . Springer International Publishing.

Badgett, M. V. L. (2004). Will providing marriage rights to same-sex couples undermine heterosexual marriage? Sexuality Research \& Social Policy, 1(3), 1-10. https://doi.org/10.1525/srsp. 2004.1.3.1

Badgett, M. V. L. (2009). When gay people get married. . New York, New York University Press.

Bodnar, A., \& Śledzińska-Simon, A. (2014). Between recognition and homophobia: same-sex couples in Eastern Europe, In D. Gallo \& L. Paladini \& P. Pustorino (eds.), Same-Sex Couples before National, Supranational and International Jurisdictions (pp. 211-247). Berlin Heidelberg: Springer. https://doi.org/10. 1007/978-3-642-35434-2_9

Boertien, D., \& Vignoli, D. (2019). Legalizing same-sex marriage matters for the subjective well-being of individuals in same-sex unions. Demography, 56, 2109-2121. https://doi.org/10.1007/ s13524-019-00822-1

Browne, K., \& Nash, C. (2015). Opposing sam-sex marriage by supporting civil partnerships. Resistance to LGBT equalities. In N. Barker \& D. Monk (eds.), From Civil Partnership to Same-Sex Marriage. Interdisciplinary Reflections, (pp. 61-78). London: Routledge.

Brewer, P. R. (2014). Public opinion about gay rights and gay marriage. International Journal of Public Opinion Research, 26(3), 279-282. https://doi.org/10.1093/ijpor/edu029

Cortina, C., \& Festy, P. (2020). Same-sex couples and their legalization in Europe: laws and numbers. In M. Digoix (eds.) Same-Sex Families and Legal Recognition in Europe. (pp.45-71). European Studies of Population, vol 24. Cham: Springer. https://doi. org/10.1007/978-3-030-37054-1_3

De Filippis, J. N., Yarbrough, M. W., \& Jones, A. (2018). Queer activism after marriage equality. . Routledge.

Declaration Nr 1/19, the Regional Council of the Małopolskie Province, https://bip.malopolska.pl/umwm,a,1594074,deklaracja-nr119-sejmiku-wojewodztwa-malopolskiego-z-dnia-29-kwietnia2019-r-w-sprawie-sprzeciwu-wo.html

Dinno, A., \& Whitney, C. (2013). Same sex marriage and the perceived assault on opposite sex marriage. PLOS ONE, 8(6), e65730. https://doi.org/10.1371/journal.pone.0065730

Eurobarometer on Discrimination 2019: The social acceptance of LGBTI people in the EU. European Commision, published 23 September 2019

European Commission. (2020). Communication from the Commission to the European Parliament, the Council, the European Economic and Social Committee and the Committee of the Regions Union of Equality: LGBTIQ Equality Strategy 20202025. Brussels. https://eur-lex.europa.eu/legal-content/EN/ TXT/?uri=CELEX:52020DC0698

Florida, R. (2002). The economic geography of talent. Annals of the Association of American Geographers, 92(4), 743-755.

Foblets M. C., Alidadi K. (2020). Between sovereignty and transnationalism: The European Union as an Incomplete "Transnational Legal Space”. In C.J. Greenhouse, \& Ch. L. Davis. Landscapes of Law: Practicing Sovereignty in Transnational Terrain, (pp.231-232). Philadelphia, Pennsylvania: University of Pennsylvania Press. https://doi.org/10.9783/9780812297119

Gates, G. J. (2014). Lesbian, gay, bisexual, and transgender family formation and demographics. In W. Swan (eds.), Gay, Lesbian,
Bisexual, and Transgender Civil Rights (pp. 22-36). New York. Routledge, https://doi.org/10.1201/b17485

Gerstmann, E. (2008). Same-sex marriage and the constitution. . Cambridge University Press. https://doi.org/10.1017/CBO9780511619762

Górska, P., \& Mikołajczak, M. (2015). Tradycyjne i nowoczesne uprzedzenia wobec osób homoseksualnych w Polsce. In A. Stefaniak, M. Bilewicz, \& M. Winiewski (Eds.), Uprzedzenia w Polsce. (pp. 179-206). Wydawnictwo Liberi.

GUS. (2020). Household budget survey in 2019. . Statistics Poland.

Graham, M. (2004). Gay marriage: whither sex? Some thoughts from Europe. Sexuality Research \& Social Policy, 1(3), 24-31. https://doi.org/10.1525/srsp.2004.1.3.24

Harrison, B. F., \& Michelson, M. R. (2017). Listen, We Need To Talk: How to Change Attitudes about LGBT Rights. . Oxford University Press.

Hildebrandt, A. (2015). Christianity, Islam and modernity: Explaining prohibitions on homosexuality in UN Member States. Political Studies, 62, 852-869. https://doi.org/10.1111/1467-9248.12137

Hollekim, R., Slaatten, H., \& Anderssen, N. (2012). A nationwide study of Norwegian Beliefs about same-sex marriage and lesbian and gay parenthood. Sexuality Research \& Social Policy, 9, 15-30. https://doi.org/10.1007/s13178-011-0049-y

Hooghe, M., \& Meeusen, C. (2013). Is same-sex marriage legislation related to attitudes toward homosexuality? Trends in tolerance of homosexuality in European countries between 2002 and 2010. Sexuality Research \& Social Policy, 10, 258-268. https://doi.org/ 10.1007/s13178-013-0125-6

Izdebski, Z. (2012). Seksualność Polaków na poczatku XXI wieku. . Wydawnictwo Uniwersytetu Jagiellońskiego.

Kaufman, G., \& Compto, D. (2020). Attitudes toward LGBT marriage and legal protections post-Obergefell. Sexuality Research \& Social Policy. https://doi.org/10.1007/s13178-020-00460-y

Lambert, E. G., Ventura, L. A., Hall, D. E., \& Cluse-Tolar, T. (2006). College students' views on gay and lesbian issues: Does education make a difference? Journal of Homosexuality, 50, 1-30. https:// doi.org/10.1300/J082v50n04_01

Lee, M. Y. K. (2010). Equality, dignity, and same-sex marriage. A rights disagreement in democratic societies, Leiden: Martinus Nijhoff Publishers.

Lewis, G. B., \& Gossett, Ch. W. (2008). Changing public opinion on same-sex marriage: The case of California. Politics \& Policy, Vol. 36: Bristol University Press. https://doi.org/10.1111/j.1747-1346. 2007.00092.x

Linneman, T. J. (2004). Homophobia and hostility: Christian conservative reactions to the political and cultural progress of lesbians and gay men. Sexuality Research \& Social Policy, 1(2), 56-76. https:// doi.org/10.1525/srsp.2004.1.2.56

Lund-Andersen, I. (2012). The Nordic countries: Same direction different speeds. In K. Boele-Woelki \& A. Fuchs (eds.), Legal recognition of same-sex relationships in Europe. National, CrossBordee and European Perspectives (pp. 3 - 18), Cambridge-Antwerp-Portland: Intersentia.

Mariani, G. (2020). Religious diversity and party control in the states: Explaining adoptions of same-sex marriage laws. Sexuality Research \& Social Policy, 17, 119-127. https://doi.org/10.1007/ s13178-019-0379-8

McLaughlin, J., \& Casey M. E., \& Richardson D. (2006), Introduction at the intersections of feminist and queer debates. In D. Richardson, J. McLaughlin, M. E. Casey (eds.), Intersections Between Feminist and Queer Theory, University of Newcastle, UK, Palgrave Macmillan.

Merin, Y. (2002). Equality for same-sex couples. The legal recognition of gay partnerships in Europe and the United States. . The University of Chicago Press.

Mezey, S. G. (2017). Beyond marriage: Continuing battles for LGBT rights. . Rowman \& Littlefield Publishers. 
Michalska, M. (2014). Małżeństwa homoseksualne jako wyzwanie przełomu XX i XXI wieku. In G. Libor \& M. Michalska (Eds.), Wieloproblemowość - wybrane aspekty ponowoczesności. (pp. 29-44). Wydawnictwo Uniwersytetu Śląskiego.

Mizielińska, J., Abramowicz, M., \& Stasińska, A. (2014). Rodziny z wyboru w Polsce. . Instytut Psychologii Polskiej Akademii Nauk.

Nagoshi, J.L., Adams, K.A., Terrell, H.K., Hill, E.D, Brzuzy S., \& Nagoshi, C. T. (2008). Gender differences in correlates of homophobia and transphobia. Sex Roles 59, 521 (2008). https://doi.org/ 10.1007/s11199-008-9458-7

Peterson, A., Wahlstrom, M., \& Wennerhag, M. (2018). Pride parades and LGBT movements. Political participation in an international comparative perspective, New York, NY: Routledge. https://doi. org/10.4324/9781315474052

Pitoňák, M., \& Spilková, J. (2016). Homophobic prejudice in Czech youth: a Sociodemographic analysis of young people's opinions on homosexuality. Sexuality Research \& Social Policy, 13, 215229. https://doi.org/10.1007/s13178-015-0215-8

Position, the Regional Council of the Lubelskie Province, https://umwl. bip.lubelskie.pl/upload/pliki//stanowisko_LGBT_edyt.pdf

Resolution nr VIII/140/19, the Regional Council of the Podkarpackie Province, https://bip.podkarpackie.pl/images/VI_kadencja/ VIII19/140.pdf

Resolution $n r \mathrm{X} / 125 / 19$, the Regional Council of the Świętokrzyskie Province, http://bip.sejmik.kielce.pl/dopobrania/2019/6912/uchwala.nr.X. 125.2019.pdf

Rodgers, G. (2018). Being gay in Ireland: Resisting stigma in the evolving present. . Lexington Books.

Roseneil, S., Crowhurst, I., Hellesund, T., Santos, A. C., \& Stoilova, M. (2020). The tenacity of the couple-norm: Intimate citizenship regimes in a changing Europe. . University College London Press.

Schwartz, J. (2011). Whose voices are heard? Gender, sexual orientation, and newspaper sources. Sex Roles, 64, 265-275. https://doi. org/10.1007/s11199-010-9825-z
Simon, R. J., \& Abdel-Moneim, M. A. (2010). Does gender matter? Men and women on controversial social issues. Gender Issues, 27, 95-109. https://doi.org/10.1007/s12147-010-9094-8

Stone, L. (2012). Pokrewieństwo i płeć kulturowa. . Wydawnictwo Uniwersytetu Jagiellońskiego.

Tomczak, Ł. (2012). Problem legalizacji związków partnerskich osób tej samej płci w kampanii wyborczej 2011 roku. Political Preferences, 3(2012), 237-249. https://doi.org/10.6084/m9.figshare. 94198

Tomczak, Ł, \& Zawadzka, K. (2018). Polskie partie polityczne i ich wyborcy wobec związków partnerskich osób tej samej płci. Polityka i Społeczeństwo, 1(16), 132-145. https://doi.org/10.15584/ polispol.2018.1.10

Weeks, J., Heaphy, B., \& Donovan, C. (2001). Same sex intimacies: Families of choice and other life experiment. . Routledge.

Wimark, T. (2014). Is it really tolerance? Expanding the knowledge about diversity for the creative class. Tijdschrift voor Economische en Sociale Geografie, 105(1), 46-63. https://doi.org/10.1111/ tesg. 12044

Winter, B. (2018). Preserving the social fabric: Debating family, equality and polity in the UK, the Republic of Ireland and Australia. In B. Winter, M. Forest, \& R. Sénac (Eds.), Global Perspectives on Same-Sex Marriage: A Neo-Institutional Approach. (pp. 149170). Palgrave Macmillan.

Zawadzka, K. (2016). Związki partnerskie mniejszości seksualnych w programach polskich partii politycznych. Acta Politica Polonica, 1(35), 49-57. https://doi.org/10.18276/ap.2016.35-04

Zawadzka, K. (2019). Społeczność LGBT a partie i ugrupowania polityczne $w$ Polsce. . Wydawnictwo Naukowe Uniwersytetu Szczecińskiego.

Publisher's Note Springer Nature remains neutral with regard to jurisdictional claims in published maps and institutional affiliations. 